\title{
Chitosan Nanoparticles: Production, Physicochemical Characteristics and Nutraceutical Applications
}

\author{
Gomes, L. P.; Paschoalin, V. M. F.; Del Aguila, E. M.*
}

Rev. Virtual Quim., 2017, 9 (1), 387-409. Data de publicação na Web: 14 de dezembro de 2016

http://rvq.sbq.org.br

\section{Nanopartículas de Quitosana: Produção, Características Físico-Químicas e Aplicações Nutracêuticas}

\begin{abstract}
Resumo: Moléculas biologicamente ativas como a quitosana e seus derivados apresentam grande potencial de aplicação na indústria de alimentos tendo em vista a necessidade da conservação de produtos alimentícios e as crescentes preocupações em relação ao impacto ambiental negativo dos materiais utilizados nas embalagens convencionais. Quitosana é um biopolímero derivado da quitina, obtido do rejeito das atividades da indústria pesqueira. Possui uma estrutura química única, um policátion linear com alta densidade de carga, com reativos como grupamentos hidroxila e amino, e possibilidade de ligações de hidrogênios, conferindo muitas aplicações a este biopolímero. Estas características físicas e químicas e a disponibilidade, associadas à biodegradabilidade, biocompatibilidade, além de atividades antibacterianas e antifúngicas oferecem grande potencial para uso visando a segurança e preservação de alimentos. A produção de nanopartículas de quitosana por tecnologia que preserva o meio ambiente e a aplicação como novos aditivos de alimentos foi apresentada e discutida. A aplicabilidade destas nanoparticulas de quitosana como um composto antimicrobiano natural e inovador tem sido testada e relacionada às variações no peso molecular e grau de desacetilação dos biopolímeros.
\end{abstract}

Palavras-chave: Nanopartículas de quitosana; atividade antimicrobiana; revestimento e embalagem de alimentos; qualidade alimentícia; segurança e preservação de alimentos.

\section{Abstract}

Biologically active molecules such as chitosan and its derivatives have significant potential in the food industry, in view of the necessity of food product conservation and the increasing concerns regarding the negative environmental impact of conventional packaging materials. Chitosan is a biopolymer derivative of chitin, obtained from the waste of industrial fishing activities. Its unique chemical structure, such as a linear polycation chain with high charge density, reactive hydroxyl and amino groups, as well as extensive hydrogen bonding, confer a wide range of applications to this compound. These particular physical and chemical characteristics and availability, along with a short biodegradability time, biocompatibility with human tissues and antibacterial and antifungal activities offer significant potential for applications in food safety and food preservation. The production of chitosan nanoparticles by environmentally-friendly technology and its use as new food ingredient is presented and discussed. The applicability of these chitosan nanoparticles as an innovative and natural antimicrobial compound was tested considering variations in the polymer molecular weight and degree of deacetylation.

Keywords: Chitosan nanoparticles; antimicrobial activity; food coating and packing; food quality; food safety and food preservation.

\footnotetext{
* Universidade Federal do Rio de Janeiro, Instituto de Química, Av. Athos da Silveira 149, Cidade Universitária, CEP 21949-909, Rio de Janeiro-RJ, Brazil.

$M$ emda@iq.ufri.br DOI: $\underline{10.21577 / 1984-6835.20170022}$
} 


\title{
Chitosan Nanoparticles: Production, Physicochemical Characteristics and Nutraceutical Applications
}

\author{
Laidson P. Gomes, Vânia M. F. Paschoalin, Eduardo M. Del Aguila*
}

Universidade Federal do Rio de Janeiro, Instituto de Química, Av. Athos da Silveira 149, Cidade Universitária, CEP 21949-909, Rio de Janeiro-RJ, Brazil.

* emda@iq.ufrj.br

Recebido em 30 de outubro de 2016. Aceito para publicação em 14 de dezembro de 2016

\section{Introduction}

\section{Chitosan (CS)}

2.1. Physicochemical properties

2.2. CS manufacturing: enzymatic vs chemical process

2.3. CS nanoparticles production

2.4. Ultrasound applied to chitosan

3. CS applications and perspectives: food quality, food safety and food preservation

3.1. Control of spoilage microbial growth

3.2. Crops protection

3.3. Preservation of fresh and processed food quality

3.4. Food nanotechnology

\section{Conclusions}

\section{Introduction}

In recent years, the sustainable development concept has obtained important political and social attention, privileging the developing of "green technologies" and the use of "green products" over traditional ones, in order to contribute to sustainability through decreases in environmental degradation. The establishment of improved technologies to synthesize products is necessary for the progress of different areas, while at the same time reducing environmental impacts and satisfying consumer commitment to purchasing green products as a positive attitude of consumers towards environmental protection. $^{1}$

Green chemistry explores chemistry techniques and methodologies that reduce or eliminate the use or generation of feedstock, products, by-products, solvents and reagents, hazardous to human health or to the environment. $^{2}$

Two decades ago, however, a new approach to polymer synthesis was developed, employing enzymes as catalysts (enzymatic polymerization). ${ }^{3}$ In vitro enzymatic catalysis has been extensively used 
in the biosynthesis of organic compounds as a convenient and powerful tool ${ }^{4,5}$ which exhibits high efficiency, recyclability, the ability to operate under mild conditions and environmental friendliness. ${ }^{6}$

Natural biopolymers are attractive for use in different applications, such as improving human health, aiding in drug or vaccine production or even in the production of food preservatives and additives, since these compounds have inherent biocompatibility and biodegradable structures, are safe and also are more easily accepted by health surveillance regulatory and inspection institutions.

Natural biopolymers are produced in living cells by enzymatic catalysis. Research on discovering new enzymes and on the mechanisms of enzymatic reactions have been among the most important central topics in diverse fields such as organic chemistry, medicinal chemistry, biochemistry, polymer chemistry and pharmaceutical chemistry ${ }^{7}$. Currently, many thousands of enzymes are commercially available, and some have suffered modifications for industrial applications.

On the other hand, all in vivo enzymatic reactions have the following characteristics: high catalytic activity (high turnover number), reactions under mild conditions with regard to temperature, pressure, solvent, $\mathrm{pH}$ of the medium, among others, bringing about energetic efficiency, and high reaction selectivity of regio-, enantio-, chemo-, and stereo regulations, giving rise to perfectly structure-controlled products. If these in vivo characteristics could be obtained for in vitro enzymatic polymer synthesis, the following outcomes may be expected: perfect control of polymer structures, creation of polymers with new structures, clean and selective processes without forming byproducts and a low loading process that saves energy, in addition to biodegradable properties of polymer product, in many cases. These are indicative of the "green" nature of in vitro enzymatic catalysis for the development of new polymeric materials, and, in the polymer area, green chemistry has increasingly been deemed of interest. ${ }^{8}$

This review reports the production of chitosan (CS) and chitosan nanoparticles by green techniques and will conduct an overview of CS biological properties and its potential applications as a food additive and preservative.

\section{Chitosan (CS)}

Several sources have been used for the production of chitosan from chitin, but the most exploited sources of chitin are the processing waste of shellfish and marine crustaceans, especially shrimp, lobster, crab, oysters, krill and squid. ${ }^{9}$ Generally, marine crustacean shells contain around 15-40\% chitin (dry weight), as well as proteins and calcium carbonate. ${ }^{10}$

Commercial chitin can be found with several average degrees of acetylation (DA) ranging from the fully acetylated to the totally deacetylated products. When displaying a high degree of acetylation, this polymer is soluble in very few solvents, which limits its application. The production of chitosan is usually performed in heterogeneous conditions, and, because of this, the residual acetyl substituent distribution depends on the source of chitin, on the deacetylation conditions and on the degree of residual acetylation. It is clear that the solubility of these polymers directly depends on the average DA, but also on the distribution of the acetyl groups along the polymer chains. ${ }^{11}$

Chitin shows severe limitation for large scale uses, since it is a water insoluble linear polysaccharide consisting of repeated $\mathrm{N}$ acetyl-D-glucosamine (GIcNAc) units linked by $\beta-(1 \rightarrow 4)$ glycosidic bonds (Figure 1), as explained above. However, water soluble derivatives can be produced after a chitin deacetylation process. The totally deacetylated chitin produces a CS molecule which contains an $-\mathrm{NH}_{2}$ group and two $-\mathrm{OH}$ radicals in each glycoside residue, displaying a polycationic character formed by $-\mathrm{NH}_{3}{ }^{+}$ 
radicals when the $\mathrm{pH}$ of aqueous solutions is lower than its pKa. ${ }^{12}$ The relative amount of these two monomers (2- amine and 2acetamide) can be modified between CSs, depending on the extraction and production methods and the organisms used as the source for chitin extraction. The production of biopolymers with different physicochemical characteristics, due to distinct degrees of deacetylation (DD), is a consequence of the amount of deacetylated radicals (2-amine) present in the sample, varying between 60 and $95 \%$ DD in CS polymers.

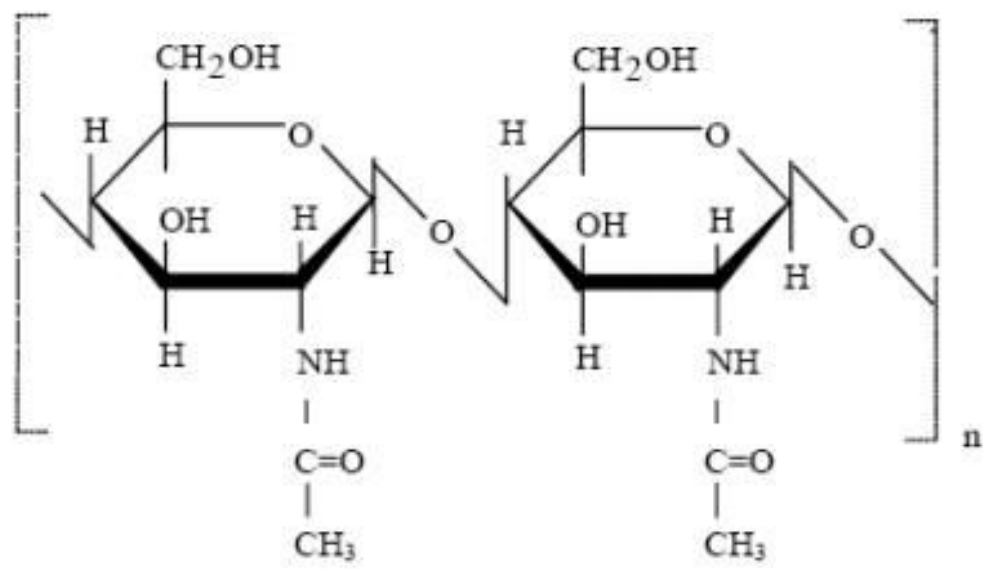

(a) Chitin

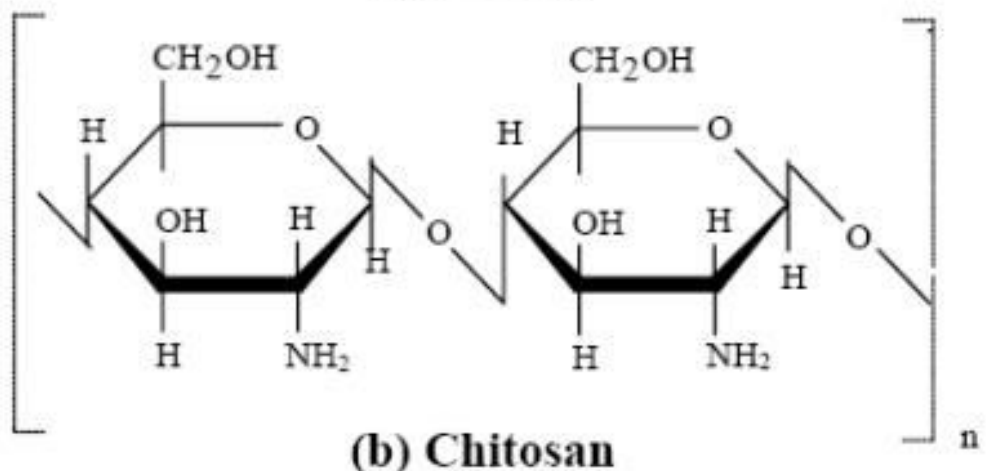

Figure 1. Molecular structures of (a) chitin and (b) chitosan ${ }^{12}$

The role of CS particles in foods can be viewed in broad categories where they can improve food quality, safety and preservation. CS and CS-particles can, thus, be categorized based on their functions, such as antimicrobial properties, as well as additive properties, including roles such as color stabilization, emulsification, antioxidant activities and dietary fiber-like properties, aiding water-holding and fat entrapment, thereby also imparting health benefits. Due to the multifunctional properties of chitosan, in the last decade the number of patents issued on the processing of chitosan and its derivatives related to use in food industry has increased. ${ }^{13}$

\subsection{Physicochemical properties}

CS is insoluble in both organic solvents and water. It can, however, be readily dissolved in weak acidic solutions, due to the presence of its amino groups. The solubility and acid-base behavior is directly dependent 
on the DD characteristics, defined as the glucosamine/N-acetyl glucosamine ratio. ${ }^{14}$ Water-soluble chitosan derivatives can be obtained by the introduction of permanent positive charges in the polymer chains, resulting in a cationic polyelectrolyte, independent of the $\mathrm{pH}$ of the aqueous medium. According to Xie et al. (2002), ${ }^{15}$ at neutral $\mathrm{pH}$, the degree of protonation of $\mathrm{NH}_{2}$ is very low, so $\mathrm{NH}_{3}^{+}$repulsion is weak. Solubilization occurs by protonation of the $\mathrm{NH}_{2}$ on the $\mathrm{C}-2$ position of the D-glucosamine repeated unit at $\mathrm{pH}$ lower than 6.2 (the pKa of CS); thus the polysaccharide is converted to a polyelectrolyte in acidic media. ${ }^{16} \mathrm{~A}$ soluble CS product is obtained when the DD reaches $60-85 \%$ or higher. ${ }^{17}$ The positive charge of the amine group $\left(\mathrm{NH}^{3+}\right)$ at lower $\mathrm{pH}$ values than the $\mathrm{pKa}(\mathrm{pH}<6.2)$, is directly involved in the interaction of CS with negatively charged microbial cell membranes, a phenomenon which may cause leakage of intracellular constituents, leading to the microbial cell death. ${ }^{18}$

Molecular weight (MW) is also a fundamental characteristic; alongside DD it may contribute to the solubility of CS biopolymers, thus explaining seemingly controversial results. MW modifications alter the content of $\mathrm{N}$-acethylglucosamine units in $\mathrm{CS}$, which have both an intramolecular and intermolecular influence, resulting in CSs with different conformations. However, increasing CS solubility implies in control of the deacetylation of the residues, which is sometimes a low yield process. ${ }^{19}$

CS-derivatives can usually be obtained by chemical modifications of the amino or hydroxyl (especially at the C6 position in the CS backbone) groups, in order to improve their physicochemical properties. ${ }^{20}$ Structural variations can be used to modify physicochemical characteristics and direct the use of the biopolymer, and are usually obtained by chemical modifications. Many CS-derivatives have been, described such as thiolated, carboxyalkyl, bile acid-modified, quaternized $(\mathrm{N}, \mathrm{N}, \mathrm{N}$-trimethyl chitosan; $T M C$ ), sugar-bearing and cyclodextrin-linked modifications. ${ }^{21}$
2.2. CS manufacturing: enzymatic vs chemical process

Chitin purification and CS manufacturing can be carried out by different chemical or enzymatic methods. The most common method for CS synthesis is the deacetylation of chitin using $\mathrm{NaOH}$, which requires chitin exposure to a combination of severe chemical and thermal conditions. This process results in a significant yield, but higher DDs require more severe treatment conditions. To obtain CS with a DD between 85 and $92 \%$, chitin should be exposed to harsh alkaline conditions, which may result in degradation. At the same time, there is high consumption of water and energy, as well as impacts on the environment due the large volume of discarded solvents and alkali ${ }^{22}$. Partial depolymerization is obtained by applying physical methods, such as irradiation with low-frequency ultrasound (20 $\mathrm{kHz}$ ), reducing the average $\mathrm{MW}$ from 2000 $\mathrm{kDa}$ to $450 \mathrm{kDa}$ or from $300 \mathrm{kDa}$ to $50 \mathrm{kDa}$; however, this MW decrease is limited. ${ }^{23}$

The enzymatic process for chitin purification is very well explained by Hamed et al. (2016), ${ }^{24}$ where CS can be manufactured by enzyme-catalyzed processes that replace alkaline or acid chitin treatments, saving energy, water and chemicals, which helps to improve product quality, and, furthermore, presents valuable environmental benefits. As mentioned previously, these protective environmental claims are becoming more important at a time of increasing awareness regarding sustainable development, green chemistry, climate change and organic production ${ }^{25}$. Different hydrolytic enzymes able to catalyze the cleavage of CS glycoside bonds have been isolated. ${ }^{26,27}$ Cellulases, pectinases, pepsins, papains, neutral proteases, lipases and $\alpha$ amylases show the ability to hydrolyze $\mathrm{CS}$ at comparable activity levels, but with different specificities. ${ }^{28-30}$

Our research group focused on the production of CS by a binary enzyme system, comprised by a hydrolytic step catalyzed by 
chitinase purified from grapes ${ }^{31}$, followed by a subsequent deacetylation, where the removal of the acetate radical from the chitin D-glucosamine monomers is catalyzed by a recombinant chitin deacetylase enzyme from baker's yeast but cloned in Pichia pastoris. ${ }^{32}$ The aforementioned enzymes can be obtained from different organisms and their use for chitin hydrolysis has been explored in order to improve the process efficiency and control over the physicochemical characteristics of the formed products. These enzymes are capable of reducing chitin crystallinity, and the assay conditions can be adjusted to produce chitosan macromolecules with distinct molecular weights (MW) between $4.0-10.0 \mathrm{kDa}$. Moreover, CS presenting distinct MWs and distinct DDs can be obtained if enzymes able to promote deacetylation of 2-acetamido monomers are associated to the hydrolytic process, according to the intended usage of the synthetized polymers. ${ }^{28,32}$

The production of large amounts of toxic waste and higher power consumption is observed in chemical methods in comparison to enzymatic methods and the formed products are heterogeneous, with variable $\mathrm{MWs}$ and $\mathrm{DDs}^{33}$. The homogeneity in size and DD of the formed CS is very important for the subsequent application of the generated product and higher uniformity will create better market value, since CS may be used in several different types of applications. ${ }^{34}$ The homogeneity of the resultant CS polymers leads to the choice of the binary enzyme treatment of chitin over the alkaline alternative.

\subsection{CS nanoparticle production}

Nanotechnology has potential to produce new food ingredients and innovative products, with considerable benefits to human health ${ }^{35}$ through the development of new structures to be used as nutraceutical polymers in fruits, seeds, vegetables and potable water, among others. ${ }^{36}$ The consumption of foods providing extra health benefits as well as basic nutrition is very attractive to the consumer, and significant developments in the food industry have emerged in recent years.

Nanoparticles (NPs) prepared from either synthetic polymers or natural polymers have been involved in several applications. The potential application of a nanoparticle depends on certain factors, such as the type of material ${ }^{37}$ and particle shape ${ }^{38}$ and concentration. ${ }^{39}$ The intrinsic properties of NPs are determined predominantly, by their size, composition, crystallinity and morphology. ${ }^{40}$ The chemical composition of NPs, their surface shape, charge, hydrophobicity, besides size ${ }^{41}$ and the presence or absence of functional groups or other chemical compounds ${ }^{42}$ define the applications of these compounds.

Indeed, CS has been explored as a material of choice to produce NPs in the last years due to its biodegradability and biocompatibility ${ }^{43}$. The unique character of NPs, such as small size and quantum size effect could result in chitosan nanoparticles (CSNP) with many new application possibilities. They are simple and inexpensive to manufacture, their production process can be scaled-up, and they show unique sizes and large surface-to-volume ratios. ${ }^{44}$

Distinct methodologies have been used to prepare CSNP, and the selection of the preparative method depends on factors such as particle size requirement, thermal and chemical stability of the active agent, reproducibility of the release kinetic characteristics, stability of the final product and residual toxicity associated with the final product. ${ }^{45}$ However, the selection of any of these methods depends on the nature of the active molecule, as well as the type of delivery device.

Even though chitosan nanoparticles (CSNP) appear to be safe in laboratory-scale studies, the knowledge of the risks involved in real-world applications leaves much to be desired. ${ }^{46}$ The application of these particles 
on the macroscale is questionable, since nanomaterials exhibit novel properties due to their extremely small size, high surface area and reactivity. ${ }^{47,48}$

The early findings of the use of these nanoparticles in favor of human beings are promising signs for their possible safe environmental applications. However, some doubts have risen with regard to the use of nanoencapsulated food additives and nanocoated films in food packaging. ${ }^{49}$ Their complete toxicity effects have not yet been studied, and additional exposure assessments are required in order to obtain a better picture of the relationships between nanoparticle applications and their health risks. Most of the time, the risks regarding nanoparticles are assessed by their chemical composition and, to date, no widely accepted or well-defined risk assessment methods or test strategies explicitly designed for NPs exist. ${ }^{50}$ It is, thus, essential to gather more information regarding health and environmental risks associated with nanoparticle applications, in order to identify the proper risk assessment strategies and implement regulatory policies to ensure the safety of these nanomaterials.

\subsection{Ultrasound applied to chitosan}

One of the most promising technologies for the conversion of raw biomass material is ultrasonic irradiation, which offers the possibility to rupture polymeric carbohydrates and convert them into useful lower weight molecules. ${ }^{25,28,51}$ Ultrasound application is one of the most economical and simple tools for the degradation of long polymeric macromolecules, breaking up aggregates and reducing the size and polydispersity of nanoparticles ${ }^{52}$. The application of ultrasound through temperature, frequency and intensity control and polymer concentrations, the extent of the degradation is mainly determined by the sonication time $(t s)^{6,53}$
Recent studies have further investigated the effects that ultrasound treatments can cause in polymer macromolecules, and verified altered properties like chemical composition, size, shape, surface charge density, hydrophobicity, ${ }^{41}$ polydispersity and the presence or absence of functional groups or other chemical agents ${ }^{42}$ when subjected to different treatment conditions. ${ }^{54}$

Perhaps the most relevant evidence regarding the ultrasonic degradation of CS supports that scission occurs mainly through the $\beta(1 \rightarrow 4)$ linkage and that DD remains barely unaffected, even during long sonication times. ${ }^{6,55}$ Consequently, the unaltered DD and the possibility of controlling molecular mass make ultrasonication a likely choice for preparing CS nanoparticles. However, the physical stability and in vivo distribution of nanoparticles are known to be affected by their mean size, polydispersity, and surface charge density ${ }^{56}$ and should be tested before their use in biological systems.

\section{CS applications and perspectives: food quality, food safety and food preservation}

The growing number of scientific papers and patents regarding CS or CS nanoparticles and their applications demonstrates a surprisingly high level of research on this biopolymer. The number of publications related to CS applications in different technological areas in the last years is growing: in 2016, 4812 publications were available, more than two times the number of publications (2084) in 2010. Sixteen years ago, not even one thousand publications were available per year (928), demonstrating the increase in the study and importance of this biopolymer (Figure 2). 


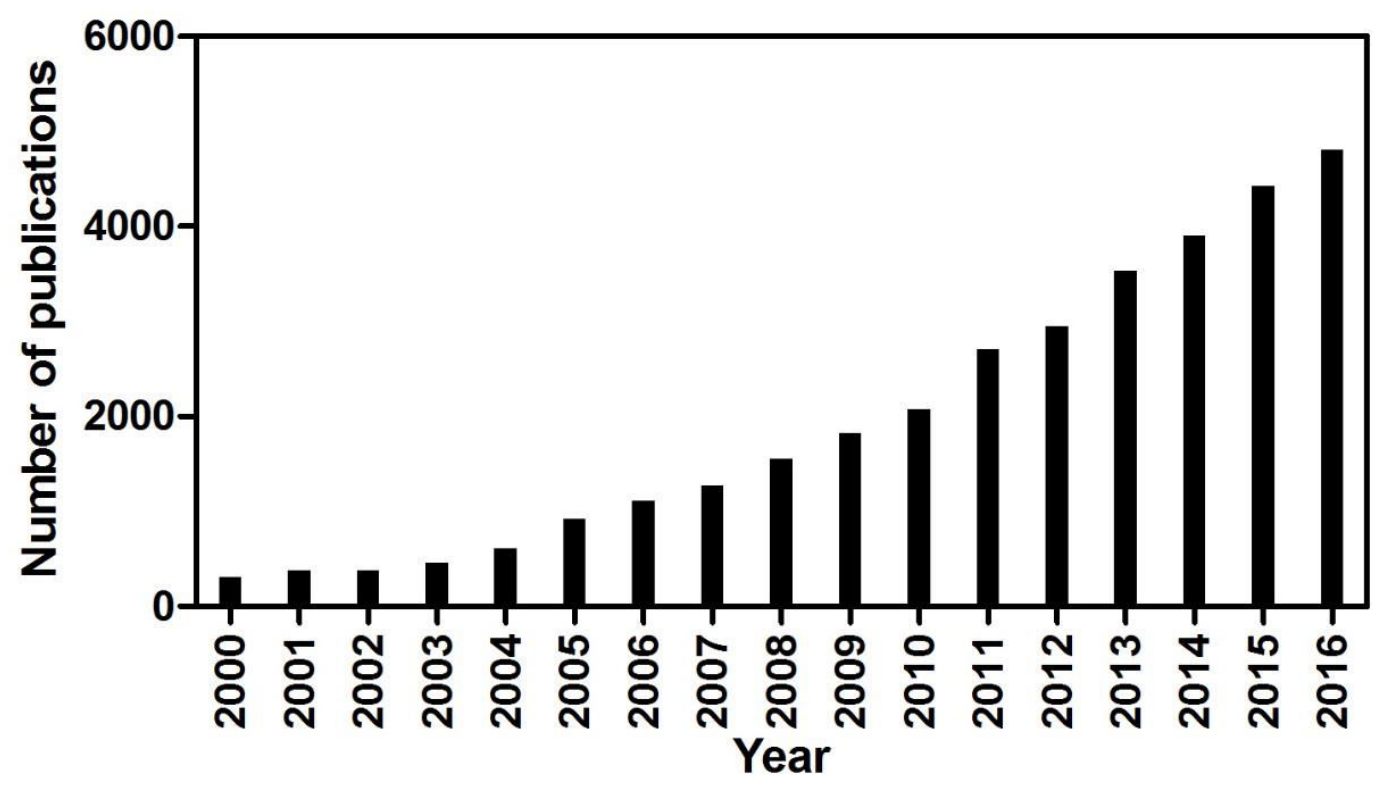

Figure 2. Data obtained from the website sciencedirect.com - August/2016-15:00 h, search using the following words: Chitosan and Application

Areas of particular CS or CNSP applications in the past 16 years are the pharmaceutical industry, including tissue engineering and drug transport, which correspond to 20 and $21 \%$, respectively. However, the versatility of CS applications can be demonstrated by the variety of uses in many areas, ranging from metal-contaminated water purification to the formation of nanotubes and use as an antimicrobial agent. This versatility directly contributes to the growth of studies conducted with this macromolecule, which is intrinsically related to new applications of this biopolymer (Figure 3). The Food and Drug Administration (FDA) agency in the U.S. approved CS as a food additive in 1983. Since it is considered a Generally Recognized as Safe (GRAS) compound, CS has, thus, been widely applied as a functional food, in environmental protection and as a safe biotechnology product to be used to promote health in human beings and animals. ${ }^{57}$

Many biological activities have been reported for CS, such as antimicrobial, anticancer, antioxidant, and immune stimulatory effects, that are dependent on its physicochemical properties (Table 1). Food applications have already been approved by the Regulatory Agencies regarding food consumption and drug administration in Japan, Italy and Finland, as well as the U.S. ${ }^{58}$ 


\section{CHITOSAN APPLICATIONS}

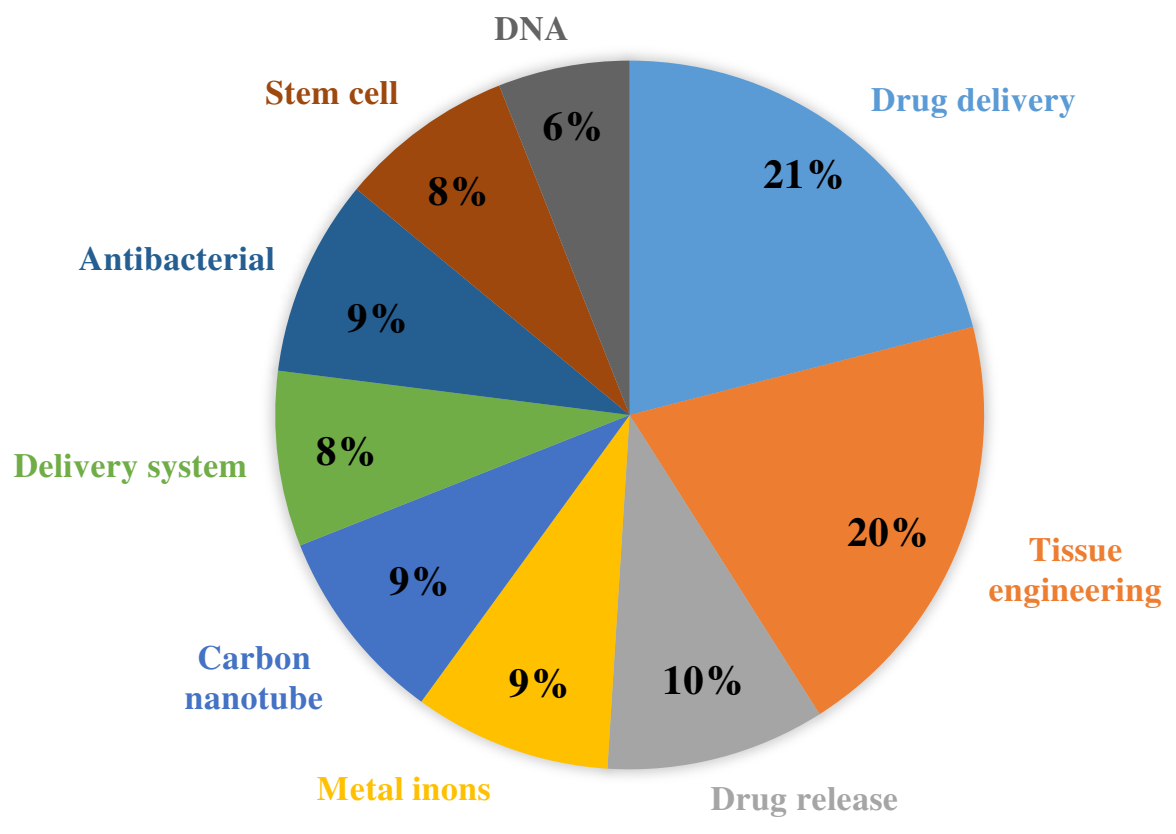

Figure 3. Major chitosan applications Source: sciencedirect.com - June/2015-21:00. Search using the following words: "Chitosan" and "Application", between 2000 and 2015

Table 1. Chitosan and chitosan-derivatives used as nutraceuticals for improving food quality, safety and preservation ${ }^{78}$

\begin{tabular}{ccc}
\hline Use & Example & Ref. \\
\hline $\begin{array}{c}\text { Antimicrobial } \\
\text { agent }\end{array}$ & Bactericidal, fungicidal; measure of mold contamination in agricultural \\
commodities. & 127, \\
\hline $\begin{array}{c}\text { Edible film } \\
\text { industry }\end{array}$ & $\begin{array}{c}\text { Controlled moisture transfer between food and the surrounding } \\
\text { environment; controlled release of antimicrobial substances, } \\
\text { antioxidants, nutrients; reduction of partial oxygen pressure; controlled } \\
\text { rate of respiration: temperature control }\end{array}$ & $129-132$ \\
\hline Additives & $\begin{array}{c}\text { Clarification and deacidification of fruits and beverages, natural flavor } \\
\text { extender, texture controlling agent, emulsifying agent, colour } \\
\text { stabilization }\end{array}$ & 133,134 \\
\hline Nutritional \\
quality & $\begin{array}{c}\text { Dietary fiber; hypocholesterolemic effect; livestock and fish feed } \\
\text { additive, reduction of lipid absorption; production of single cell } \\
\text { proteins; antigastritic agent }\end{array}$ & 80,135, \\
\hline $\begin{array}{c}\text { Purification of } \\
\text { potable water }\end{array}$ & Recovery of metal ions, pesticides phenols and PCB's; removal of dyes & 136 \\
\hline
\end{tabular}




\subsection{Spoilage microbial growth control}

Among the different CS bioactivities, perhaps the most applicable in the food chain production is its antimicrobial activity, enhancing food safety and preservation, while also impacting biosecurity, the food business and community health, since it can be effective in controlling foodborne pathogens without antibiotics. The antimicrobial activity of CS is influenced by several intrinsic and extrinsic factors, which can be classified into 4 categories (a) microbial factors related to the species of the target organism and cell age; (b) chemical properties of the CS molecule (density of positive charges, MW, concentration, hydrophilic/hydrophobic characteristics and chelating potential); (c) CS physical state and water solubility and (d) environmental factors (ionic strength of the medium, $\mathrm{pH}$, temperature and pathogen exposure time pathogen). ${ }^{59}$

CS presents antimicrobial activity against a broad spectrum of microorganisms, including Gram-positive and Gram-negative bacteria, filamentous fungi and yeast ${ }^{59}$.

CS exerts antifungal effects on different fungi developmental stages by suppressing sporulation, spore germination, mycelial growth, spore viability and the production of virulence factors. ${ }^{60}$

The observed antibacterial activity is a complicated process that differs between Gram-positive and Gram-negative bacteria, due to their distinct cell surface characteristics. Discrepancies exist however, since in several studies CS displays stronger antibacterial activity against Gram-negative when compared to Gram-positive bacteria ${ }^{61}$, while in other studies Gram-positive bacteria were more susceptible. ${ }^{62,63}$

Some studies described the mechanism of action as a result of the interaction between the CS macromolecules, that are positively charged, and the membrane of the microbial cell, that is negatively charged, with subsequent breakage and, consequently, leakage of intracellular components, including proteins and nucleic acids. ${ }^{64,65}$

Besides causing alterations in cell membrane permeability, ${ }^{66}$ CS antimicrobial activity is enhanced by its ability to act as a chelating agent, selectively binding to trace metals, thus inhibiting the toxin production and microbial growth. CS also activates various defense processes in the host tissue, acting as a binding agent to water and as an inhibitor to several enzymes. ${ }^{67}$

The alternative mechanism microbial growth inhibition by the interaction between the positively charged CS and intracellular fungi and bacteria DNA, which consequently inhibits the RNA and protein synthesis, is considered effective only for low molecular weight chitosans (LMW-CS), which can penetrate microorganism cells. Although this mechanism of action based on ionic interactions with DNA is still controversial, it could explain the inhibition of both Grampositive and Gram-negative bacteria and fungi by CS, establishing a similar mechanism of action for all microorganisms, regardless of their cell membrane structure. ${ }^{68}$

CS definitely demonstrates a strong inhibitory effect on microorganisms growing in low $\mathrm{pH}$ media, confirmed by the fact that its antimicrobial activity is weakened with increasing $\mathrm{pH}$ values, ${ }^{69}$ causing low protonation of amino groups, which in turn also influences the solubility of the biopolymer, causing decreases. ${ }^{70,71}$

Due to apparent discrepancies, the interactions of CS and its derivatives with the outer membrane barrier of bacteria should be better understood, but they certainly depend on the binomial combination of MW and DD.

LMW-CS of less than $10 \mathrm{kDa}$ have greater antimicrobial activity compared to high molecular weight chitosan (HMW- CS), ranging between 10 and $500 \mathrm{kDa} .{ }^{72}$ However, studies conducted with hydrochloride Dglucosamine, demonstrated that the CS monomer was not effective in inhibiting 
bacterial growth, suggesting that the antimicrobial activity of CS is related not only to the cationic nature of the deacetylated glucosamine, but also to the chain length of the biopolymer. ${ }^{73}$

Although some results regarding the bactericidal activity of LMW-CS are comparable, it has been reported that, depending on the bacteria strain, the conditions of the biological assays and CS physico-chemical characteristics (MW and $\mathrm{DD})$, the results are not always in agreement with each other. Studies testing the $9.3 \mathrm{kDa}$ CS have shown inhibition of $E$. coli growth, while the 2.2. $\mathrm{kDa} C S$ promotes the growth of the same bacteria. ${ }^{74}$ On the other hand, the 4.6 kDa CS was most active against Gram positive bacteria, yeast and fungi. ${ }^{75}$ Thus, results with LMW-CS are still somewhat controversial and unclear, indicating that additional experimental data are required to understand the antimicrobial mechanisms that take place.

Evaluating these studies, it seems that CS antimicrobial action depends on MW, but also on the different physical states of the polymer and its derivatives, that may, thus, provide distinct mechanisms of growth inhibition. Similar to the LMW-CS, watersoluble ultrafine nanoparticles can penetrate bacteria cell walls, interfering in the microorganism nuclei by binding to DNA and RNA, as well as inhibiting both the mRNA and protein synthesis. ${ }^{68}$

Despite the apparent discrepancies regarding CS effects, the natural antimicrobial properties of CS and its derivatives have resulted in their extensive use as commercial disinfectants, since some CS have an advantage over other disinfectants due to their high antimicrobial and broad spectrum of activity but low toxicity to mammalian cells, allowing them to be discarded with less damage to the environment. $^{76}$

Recently, it has been demonstrated that bioplastic films composed by CS and its derivatives also display antimicrobial activity. The potential use of CS-based films and their derivatives may be directly dependent on particle size, film thickness and the structure of the matrix-forming fibers. In a previous study, two CS films with distinct structures and particle sizes were tested, where particles ranged between 74-500 $\mu \mathrm{m}$ (resembling a flake), and between 37-63 $\mu \mathrm{m}$ (resembling a sphere). The films exhibited superior antimicrobial activity against $S$. aureus when smaller-sized, spherical shaped particles were used, which provides greater specific surface contact. ${ }^{77}$

It is accepted that CS nanoparticle-based films can be effectively used in the food industry, as they provide various benefits, including good edibility, biocompatibility with human tissues, an aesthetically pleasing appearance, displaying barrier properties against pathogenic microorganisms, atoxicity, and are non-polluting and made from low cost material. ${ }^{78}$

Table 1 lists some applications of CS and its derivatives on food quality, food safety and food preservation.

\subsection{Crop protection}

CS can also be used primarily as a natural seed treatment and plant growth enhancer, since it is considered an ecologically friendly biopesticide substance that boosts the innate ability of plants to defend themselves against fungal infections. ${ }^{79}$ CS applications in plants and crops are regulated by the EPA and USDA National Organic Program, which regulates its use on certified farms and crops as using organic production system ${ }^{80}$. EPA-approved, biodegradable CS products are allowed for use outdoors and indoors on plants and crops both grown commercially or home grown. ${ }^{81}$

CS has prevented numerous pre- and post- harvest diseases on various horticultural commodities. Microscopic observations indicate that CS had a direct effect on the morphology of CS-treated microorganisms reflecting its fungistatic or fungicidal potential. In addition to a direct antimicrobial activity, other studies have 
strongly suggested that CS induces a series of host defense reactions related to the enzymatic activities of the host organism. ${ }^{57}$

The foliar application of CS in pepper plants decreased transpiration and reduced water use by $26-43 \%$, while maintaining biomass production and yield. Hence, CS might be an effective antitranspirant product to conserve water use in agriculture. ${ }^{82,83}$ Reports are also available indicating that coating seeds with depolymerized CS or its oligosaccharides typically increases chitinase activity in seedlings by $30-50 \%$, unless the seeds have a hard cuticle. A $5 \mathrm{kDa}$ LMW-CS induced the accumulation of phytoalexins in plant tissue and decreased total content and changed the composition of free sterols, producing adverse effects on infesters, by the activation of chitinase and beta-glucanase enzymes, as well as lipoxygenase enzyme activity, by stimulating the generation of reactive oxygen species. ${ }^{84}$

In addition, CS can also induce structural barriers, for example, triggering the synthesis of a lignin-like material. For some horticultural and ornamental commodities, CS increased harvested yield, due to its ability to form a semipermeable coating. Cs also extended the shelf life of treated fruit and vegetables by minimizing the rate of respiration and reducing water loss. It was observed that CS at 0.1 or $0.5 \%$ increased leaf area, leaf dry weight and leaf length of soybean, lettuce and rice, whereas CS at 0.1 $\%$ showed positive effects on leaf area, leaf length and dry weight of tomato. ${ }^{85}$ As a nontoxic biodegradable material, as well as an elicitor, CS has the potential to become a new class of plant protectant, assisting towards the goal of sustainable agriculture. ${ }^{60}$

\subsection{Preservation of fresh and processed} food quality

Conventional food packaging systems are supposed to passively protect food, acting as a barrier between the packaged food and the surrounding environment. Antimicrobial food packaging systems have received considerable attention since they help control the growth of pathogenic and spoilage microorganisms on food surfaces, where microbial growth predominates ${ }^{86}$. Antimicrobial nanocomposite systems are particularly interesting, since materials in the nanoscale range have a higher surface-tovolume ratio when compared to their microscale counterparts. Nano-materials are thus more efficient, since they are able to attach themselves to more copies of microbial molecules and cells. ${ }^{87}$

CS films have shown potential to be used as a packaging material for the quality preservation of a variety of foods. CS has also been widely used in antimicrobial films to provide edible protective coating, and in the dipping and spraying of food products, due to its antimicrobial properties. ${ }^{88}$

Coatings based on CS have been used as an antifungal agent, which resulted in the enhancing of germination and quality of artichoke seeds. The effect of the formulation and thickness on seed germination (G\%), fungi activity and vegetative growth were evaluated, and results indicated that significant differences between treatments regarding seed germination were observed, where all CS coatings reduced the number of fungi strains and increased plant growth. ${ }^{89}$

In another study, apples (Malus domestica Borkh. cv. Gala) were heat-treated at $38{ }^{\circ} \mathrm{C}$ for 4 days (heat treatment) before or after being coated by $1 \% \mathrm{CS}$. The combination of the heat treatment plus CS fruit coating showed the lowest respiration rate, malondialdehyde levels, membrane leakage, ethylene evolution and the highest firmness and consumer acceptance among the treatments. ${ }^{90}$

When applied on wounded wheat leaves, CS induced lignification and, consequently, restricted the growth of nonpathogenic fungi in wheat. CS also inhibited the growth of $A$. flavus and aflatoxin production in liquid cultures, pre-harvest maize and groundnut, 
and enhanced phytoalexin production in germinating peanut plants ${ }^{91}$. In addition, CS also improved the microbiological quality of fresh cut broccoli. ${ }^{92}$

Edible coatings consisting solely of CS or a combination of CS with other biopolymers, such as sodium caseinate, were applied to carrots, cheese and salami. ${ }^{93}$ The sodium caseinate/CS films inhibited bacteria and yeast growth and can be potentially applied to several food matrices. In other studies, acetic or propionic acid were incorporated into a CS matrix in Bologna ham, baked ham and fresh salmon, ${ }^{94}$ with positive effects.

The application of high concentrations of CS is considered effective in the control of fruit colouring, decreasing fruit darkening and maintaining anthocyanin content, a pigment directly related to food freshness. Enzyme activity is influenced by the presence of $\mathrm{O}_{2}$ concentrations inside the fruit. CS forms a physical barrier around the fruit, and, consequently, darkening is reduced. Furthermore, the positive charges present in the coating can stabilize anthocyanine pigments, aiding in maintaining fruit colour, sensory attributes and antioxidant features. ${ }^{95}$

Other studies were performed using CS biodegradable packaging and edible coatings for the preservation of fresh-cut fruits and vegetables. ${ }^{96,97}$

The use of CS-based edible films was also tested to preserve the quality of pork meat hamburgers. Their importance in the modulation of the oxygen permeability of films in order to avoid the undesirable effects of metmyoglobin (MtMb) formation was promoted by lower partial oxygen pressure in the surface of the coated hamburgers. ${ }^{13}$

The interest in edible coatings is on the rise, due to their ability to reduce fruit respiration and transpiration rates, and consequently increase storage time and consistency retention. ${ }^{98-100}$

The use of CS also decreased the respiration rate and production of ethylene in raspberries $^{95}$ and has a high selective permeability to respiratory gases, acting as a passing barrier for $\mathrm{O}_{2}{ }^{101}$ This gas control between the fruit and the environment reduces respiration rates, as well as the enzymatic action of 1-carboxylic-1aminocyclepropane oxidase and synthases, which are highly influenced by the presence of $\mathrm{O}_{2}{ }^{102}$ The decrease of mass loss with $\mathrm{CS}$ applications has also been related to the formation of a selective barrier around the surface of the fruit, improving moisture loss and reducing respiration and the main metabolic processes that lead to loss of water. ${ }^{103,104}$

CS has also been used for juice clarification with good results for apple, carrot, grape, lemon, orange and pineapple juices ${ }^{105}$.

CS antioxidative properties, especially in food products that contain high amounts of unsaturated fatty acids, which are sensitive to oxidation during storage, have also been reported. ${ }^{106}$ CS scavenges free radicals or chelates metal ions from the donation of a hydrogen or lone pairs of electrons, increasing its antioxidant ability and free radical scavenging activity. ${ }^{107}$

\subsection{Food nanotechnology}

The United States Department of Agriculture implemented a project to develop green nanotechnology aimed at eliminating foodborne pathogens. ${ }^{108}$ In this study, the USDA envisaged the development of a nanoparticle wash treatment with the capability of significantly reducing or eliminating pathogenic bacteria associated with fresh or fresh-cut fruits and vegetables, to be used with minimal processing. The specific tasks involve the design, synthesis and characterization of ultrapotent CS nanoparticles coated by antimicrobial peptides, the evaluation of peptide-enhanced nanoparticles as a lysis agent in realistic food processing environments and the development of a postharvest nanoparticle electric field treatment for decreasing the 
bacterial loads of fresh fruits and vegetables. ${ }^{109}$

Food-grade nanoparticles and microparticles can be fabricated from a range of different ingredients, including biopolymers, lipids, surfactants, and minerals. Biopolymer particles are often classified according to their structures, such as (filled) hydrogel particles, inclusion complexes, and polyelectrolyte complexes. However, the dimensions of the biopolymer particles alter their functional performance in foods. ${ }^{110}$

Nanoparticles composed of different materials (including silicates, silver, magnesium, and zinc oxide) have been incorporated into packaging materials ${ }^{111}$, where they afford greater protection to foods due to several effects that include reduced gas and odor permeation, blocking of ultraviolet radiation, enhanced mechanical properties and thermal stability. ${ }^{112}$ Studies of the health effects of these particles are especially important, because the packaging may have direct contact with the food. ${ }^{111}$

Functional bioactive ingredients have received much attention in recent years from the scientific community, consumers and food manufacturers. Potential functional bioactive ingredients include vitamins, probiotics, bioactive peptides, antioxidants, among others.

Micro/nanostructured CS can be used as bioactive ingredient carriers and have the potential for the development of novel encapsulation or immobilization carriers 113 (Zhao et al., 2011). They also display mucoadhesive properties, which may prolong the contact time between bioactive and absorption sites, thereby increasing absorption.

CS particles are especially useful for the encapsulation of hydrophilic macromolecules, which are associated through electrostatic interactions or hydrogen bonding. ${ }^{114}$ Encapsulation of bioactive compounds is a relatively old concept and was initially focused on protecting vitamins from oxidation. ${ }^{115}$ Since then, many other types of active ingredients have been the focus of encapsulation technologies, and encapsulation is currently one of the most intensively studied application areas of microparticle and nanoparticle biopolymers. Generally, two types of active ingredients can be distinguished, bioactive molecules (nutraceuticals) and bioactive living cells (probiotics) . ${ }^{116,117}$

CS was successfully used in applications regarding the encapsulation of different bioactive compounds. ${ }^{118}$ CS produces biopolymer particles to encapsulate proteins in combination with gellan gum ${ }^{119}$ and colonspecific delivery systems for peptides and proteins ${ }^{120-122}$ demonstrated that a CS/vitamin C nanoparticle system successfully increased the shelf life and delivery of vitamin $C$ in rainbow trout during 20 days of storage.

Rajeshkumar et al. (2009) $)^{123}$ demonstrated that CS nanoparticles could be used to encapsulate DNA, which was then beneficially incorporated into shrimp feed to protect them from white spot syndrome virus. Other additives encapsulated by CS described in the literature are shark liver oil in combination with calcium alginate beads ${ }^{124}$ and tuna oil droplets. ${ }^{125}$

The use of CS nanoparticle-based edible films as food coating has been reported with respect to a variety of foodstuffs, including cheese and meat products, such as fermented sausages. ${ }^{63}$ In another study, the possibility of producing food-grade stable nanoparticles with simple processing techniques was demonstrated, using lecithin and sodium caseinate, which could be further used as base systems for the production of nanocapsules. ${ }^{126}$

\section{Conclusions}

The application of biopolymer particles in maintaining food quality, enhancing food 
preservation and guaranteeing food safety is in the exploration phase, and food companies are seeking methodologies to create healthier products without compromising their appearance and sensory perception. Studies on nanoparticles biopolymers are demonstrating that those new compounds show the ability to protect and even target the delivery of bioactive ingredients, and/or to design foods with novel physicochemical attributes.

Chitosan is, thus, a versatile food biopolymer that has a variety of applications in all areas of food science. CS possesses promising broad-spectrum antimicrobial activities, and has, accordingly, been widely studied as a food preservative to improve food quality and extend the shelf life of perishable food products. The intrinsic properties of CS may be controlled by changing the MW and DD of the biopolymers using green processes, such as enzyme treatment and ultrasonication. The controlled synthetized CS shows versatile and promising activities that can preserve functional compounds in food, protect crops in pre- and post-harvest stages and/or maintain the quality of processed food.

Inherent antibacterial properties and its film-forming ability make CS an ideal choice for use as a biodegradable antimicrobial packaging material that can be used to improve the storability of perishable foods. As it has been convincingly proved that CS films exhibit good antimicrobial activity, which can aid in extending food shelf life, it is no surprise if a widespread use of CS films is witnessed in tomorrow's food packaging, replacing films made from petroleum-derived conventional polymers

It would be important to standardize the methods used for CS and CS-nanoparticle preparations, to validate the processes and produce CS at industrial levels with simple and low-cost manufacturing, increasing its applications in the food chain.

The chemical, physical and other qualities and characteristics of such CS derived materials should be adequately tested and analytically established. Academic research and industry support could accelerate the development of these products for human use, combining efforts to develop CS-derived products that would certainly support environmental sustainability for human health and the existence of other living systems.

\section{Acknowledgments}

The authors acknowledge the financial support of Fundação Carlos Chagas Filho de Amparo à Pesquisa do Estado do Rio de Janeiro (FAPERJ, Rio de Janeiro, Brazil), Conselho Nacional de Desenvolvimento Científico e Tecnológico (CNPq, Brasília, Brazil) and Coordenação de Aperfeiçoamento de Pessoal de Nível Superior (CAPES, Brasília, Brazil).

\section{References}

${ }^{1}$ Dahl, J. A.; Maddux, B. L. S.; Hutchison, J. E. Toward Greener Nanosynthesis. Chemical Reviews 2007, 107, 2228. [CrossRef] [PubMed]

${ }^{2}$ Raveendran, P.; Fu, J.; Wallen, S. L. Completely "Green" Synthesis and Stabilization of Metal Nanoparticles. Journal of the American Chemical Society 2003, 125, 13940. [CrossRef] [PubMed]

${ }^{3}$ Kobayashi, S.; Sakamoto, J.; Kimura, S. In vitro synthesis of cellulose and related polysaccharides. Progress in Polymer Science 2001, 26, 1525. [CrossRef]

${ }^{4}$ Jones, J. B. Enzymes in organic synthesis. Tetrahedron 1986, 42, 3351. [CrossRef]

${ }^{5}{ }^{5}$ Wong, C.-H.; Whitesides, G. M.; Enzymes in synthetic organic chemistry, vol. 12, Academic Press, 1994. [CrossRef]

${ }^{6}$ Baxter, S.; Zivanovic, S.; Weiss, J. Molecular weight and degree of acetylation of highintensity ultrasonicated chitosan. Food Hydrocolloids 2005, 19, 821. [CrossRef] 
${ }^{7}$ Bruice, T. C. A View at the Millennium: the Efficiency of Enzymatic Catalysis. Accounts of Chemical Research 2002, 35, 139. [CrossRef] [PubMed]

${ }^{8}$ Kobayashi, S.; Makino, A. Enzymatic Polymer Synthesis: An Opportunity for Green Polymer Chemistry. Chemical Reviews 2009, 109, 5288. [CrossRef] [PubMed]

${ }^{9}$ Rasmussen, R. S.; Morrissey, M. T. Em Marine Nutraceuticals and Functional Foods; Barrow, C; Shahidi, F., eds.; CRC Press, 2007, cap. 6. [Link] ]

${ }^{10}$ Kurita, K. Chitin and chitosan: functional biopolymers from marine crustaceans. Marine Biotechnology 2006, 8, 203. [CrossRef] [PubMed]

${ }^{11}$ Brugnerotto, J.; Desbrières, J.; Heux, L.; Mazeau, K.; Rinaudo, M. Overview on structural characterization of chitosan molecules in relation with their behavior in solution. Macromolecular Symposia 2001, 168, 1. [CrossRef]

${ }^{12}$ Shukla, S. K.; Mishra, A. K.; Arotiba, O. A.; Mamba, B. B. Chitosan-based nanomaterials: A state-of-the-art review. International Journal of Biological Macromolecules 2013. 59, 46. [CrossRef] [PubMed]

${ }^{13}$ Vargas, M.; González-Martínez, C. Recent patents on food applications of chitosan. Recent Patents on Food, Nutrition \& Agriculture 2010, 2, 121. [CrossRef] [PubMed]

${ }^{14}$ Sorlier, P.; Denuzière, A.; Viton, C.; Domard, A. Relation between the Degree of Acetylation and the Electrostatic Properties of Chitin and Chitosan. Biomacromolecules 2001, 2, 765. [CrossRef] [PubMed]

${ }^{15}$ Xie, W.; Xu, P.; Wang, W.; Liu, Q. Preparation and antibacterial activity of a water-soluble chitosan derivative. Carbohydrate Polymers 2002, 50, 35. [CrossRef]

${ }^{16}$ Schramm, G.; A practical approach to rheology and rheometry, Haake Karlsruhe, 1994. [Link]
${ }^{17}$ Krajewska, B. Membrane-based processes performed with use of chitin/chitosan materials. Separation and Purification Technology 2005, 41, 305. [CrossRef]

${ }^{18}$ Helander, I. M.; Nurmiaho-Lassila, E. L.; Ahvenainen, R.; Rhoades, J.; Roller, S. Chitosan disrupts the barrier properties of the outer membrane of Gram-negative bacteria. International Journal of Food Microbiology 2001, 71, 235. [CrossRef]

${ }^{19}$ Kurita, K.; Kamiya, M.; Nishimura, S.-I. Solubilization of a rigid polysaccharide: Controlled partial N-Acetylation of chitosan to develop solubility. Carbohydrate Polymers 1991, 16, 83. [CrossRef]

${ }^{20}$ Martins, A. F.; Bueno, P. V. A.; Almeida, E. A. M. S.; Rodrigues, F. H. A.; Rubira, A. F.; Muniz, E. C. Characterization of $\mathrm{N}$-trimethyl chitosan/alginate complexes and curcumin release. International Journal of Biological Macromolecules 2013, 57, 174. [CrossRef] [PubMed]

${ }^{21}$ Cotter, P. D.; Hill, C.; Ross, R. P. Bacteriocins: developing innate immunity for food. Nature Reviews Microbiology 2005, 3, 777. [CrossRef] [PubMed]

${ }^{22}$ Tan, T. S.; Chin, H. Y.; Tsai, M.-L.; Liu, C.-L. Structural alterations, pore generation, and deacetylation of $\alpha$ - and $\beta$-chitin submitted to steam explosion. Carbohydrate Polymers 2015, 122, 321. [CrossRef] [PubMed]

${ }^{23}$ Mourya, V.; Inamdar, N.; Choudhari, Y. M. Chitooligosaccharides: Synthesis, characterization and applications. Polymer Science Series A 2011, 53, 583. [CrossRef]

${ }^{24}$ Hamed, I.; Özogul, F.; Regenstein, J. M. Industrial applications of crustacean byproducts (chitin, chitosan, and chitooligosaccharides): A review. Trends in Food Science \& Technology 2016, 48, 40. [CrossRef]

${ }^{25}$ Kang, L.-X.; Liang, Y.-X.; Ma, L.-X. Novel characteristics of chitin deacetylase from Colletotrichum lindemuthianum: Production of fully acetylated chitooligomers, and hydrolysis of deacetylated chitooligomers. 
Process Biochemistry 2014, 49, 1936. [CrossRef]

${ }^{26}$ Aziz, M. A.; Cabral, J. D.; Brooks, H. J. L.; Moratti, S. C.; Hanton, L. R. Antimicrobial properties of a chitosan dextran-based hydrogel for surgical use. Antimicrobial Agents and Chemotherapy 2012, 56, 280. [CrossRef] [PubMed]

${ }^{27}$ Leceta, I.; Guerrero, P.; Ibarburu, I.; Dueñas, M. T.; de la Caba, K. Characterization and antimicrobial analysis of chitosan-based films. Journal of Food Engineering 2013, 116 , 889. [CrossRef]

${ }^{28}$ Gomes, L. P.; Andrade, C. T.; Silva, J. T.; Del Aguila, E. M.; Paschoalin, V. M. F. Green Synthesis and Physical and Chemical Characterization of Chitosans with a High Degree of Deacetylation, Produced by a Binary Enzyme System. Journal of Life Sciences 2014, 8, 7. [Link]

${ }^{29}$ Roncal, T.; Oviedo, A.; de Armentia, I. L.; Fernández, L.; Villarán, M. C. High yield production of monomer-free chitosan oligosaccharides by pepsin catalyzed hydrolysis of a high deacetylation degree chitosan. Carbohydrate Research 2007, 342, 2750. [CrossRef]

${ }^{30}$ Muzzarelli, R. A. A.; Tomasetti, M.; Ilari, P. Deploymerization of chitosan with the aid of papain. Enzyme and Microbial Technology 1994, 16, 110. [CrossRef]

${ }^{31}$ Gomes, L. P.; Oliveira, C. I. R.; Silva, M. C.; Andrade, C. T.; Del Aguila, E. M.; Silva, J. T.; Paschoalin, V. M. F. Purificação e caracterização da quitinase de uva (Vitis vinífera L. cv Red Globe) para a produção de quitosana a partir de quitina de camarão. Quimica Nova 2010, 33, 4. [CrossRef]

${ }^{32}$ Del Aguila, E. M. G.; Andrade, L. P.; Silva, C. T.; Paschoalin, J. T.; Paschoalin, V. M. F. Biocatalytic production of chitosan polymers from shrimp shells, using a recombinant enzyme produced by pichia pastoris. American Journal of Molecular Biology 2012, 2, 9. [CrossRef]

${ }^{33}$ Tsigos, I.; Martinou, A.; Kafetzopoulos, D.; Bouriotis, V. Chitin deacetylases: new, versatile tools in biotechnology. Trends in
Biotechnology 2000, 18, 305. [CrossRef] [PubMed]

${ }^{34}$ Beaney, P.; Lizardi-Mendoza, J.; Healy, M. Comparison of chitins produced by chemical and bioprocessing methods. Journal of Chemical Technology \& Biotechnology 2005, 80, 145. [CrossRef]

${ }^{35}$ Magnuson, B. A.; Jonaitis, T. S.; Card, J. W. A Brief Review of the Occurrence, Use, and Safety of Food-Related Nanomaterials. Journal of Food Science 2011, 76, R126. [CrossRef] [PubMed]

${ }^{36}$ Huang, Q.; Yu, H.; Ru, Q. Bioavailability and delivery of nutraceuticals using nanotechnology. Journal of Food Science 2010, 75, R50. [CrossRef] [PubMed]

${ }^{37}$ Ren, G.; Hu, D.; Cheng, E. W. C.; VargasReus, M. A.; Reip, P.; Allaker, R. P. Characterisation of copper oxide nanoparticles for antimicrobial applications. International Journal of Antimicrobial Agents 2009, 33, 587. [CrossRef] [PubMed]

${ }^{38}$ Wang, R. H.; Xin, J. H.; Tao, X. M. UVBlocking Property of Dumbbell-Shaped ZnO Crystallites on Cotton Fabrics. Inorganic Chemistry 2005, 44, 3926. [CrossRef] [PubMed]

${ }^{39}$ Kim, B.; Kim, D.; Cho, D.; Cho, S. Bactericidal effect of $\mathrm{TiO} 2$ photocatalyst on selected food-borne pathogenic bacteria. Chemosphere 2003, 52, 277. [CrossRef] [PubMed]

${ }^{40}$ Vigneshwaran, N.; Kumar, S.; Kathe, A. A.; Varadarajan, P. V.; Prasad, V. Functional finishing of cotton fabrics using zinc oxidesoluble starch nanocomposites. Nanotechmology 2006, 17, 5087. [CrossRef]

${ }^{41} \mathrm{Nel}$, A.; Xia, T.; Mädler, L.; Li, N. Toxic Potential of Materials at the Nanolevel. Science 2006, 311, 5. [CrossRef] [PubMed]

${ }^{42}$ Magrez, A.; Kasas, S.; Salicio, V.; Pasquier, N.; Seo, J. W.; Celio, M.; Catsicas, S.; Schwaller, B.; Forró, L. Cellular Toxicity of Carbon-Based Nanomaterials. Nano Letters 2006, 6, 1121. [CrossRef]

${ }^{43}$ Ochekpe, N. A.; Olorunfemi, P. O.; Ngwuluka, N. C. Nanotechnology and drug 
delivery part 2: nanostructures for drug delivery. Tropical Journal of Pharmaceutical Research 2009, 8, 275. [CrossRef]

${ }^{44} \mathrm{He}, \mathrm{X}$.; Hwang, H.-M. Nanotechnology in food science: Functionality, applicability, and safety assessment. Journal of Food and Drug Analysis 2016, 24, 671. [CrossRef]

${ }^{45}$ Azevedo, E. P.; Retarekar, R.; Raghavan, M. L.; Kumar, V. Mechanical properties of cellulose: chitosan blends for potential use as a coronary artery bypass graft. Journal of Biomaterials Science, Polymer Edition 2013. 24, 239. [CrossRef] [PubMed]

${ }^{46}$ Kuzma, J.; Romanchek, J.; Kokotovich, A. Upstream Oversight Assessment for Agrifood Nanotechnology: A Case Studies Approach. Risk Analysis 2008, 28, 1081. [CrossRef] [PubMed]

${ }^{47}$ Oberdörster, G.; Oberdörster, E.; Oberdörster, J. Nanotoxicology: an emerging discipline evolving from studies of ultrafine particles. Environmental Health Perspectives 2005, 823. [PubMed]

${ }^{48}$ Melo, K. C. Avaliação e modelagem reológica de fluido de perfuração base água. 2008. [Link]

${ }^{49}$ Perera, U.; Rajapakse, N.; Chitosan Nanoparticles: Preparation, Characterization, and Applications, in Seafood Processing ByProducts, Springer, p. 371-387, 2014. [Link]

${ }^{50}$ Cong, Y.; Pang, C.; Dai, L.; Banta, G. T.; Selck, H.; Forbes, V. E. Importance of characterizing nanoparticles before conducting toxicity tests. Integrated Environmental Assessment and Management 2011, 7, 502. [CrossRef]

${ }^{51}$ Savitri, E.; Juliastuti, S. R.; Handaratri, A.; Sumarno; Roesyadi, A. Degradation of chitosan by sonication in very-lowconcentration acetic acid. Polymer Degradation and Stability 2014, 110, 344. [CrossRef]

${ }^{52}$ Berne, B. J.; Pecora, R.; Dynamic light scattering with application to chemistry, biology and physics. Courier Dover: New York, 1976. [Link]
${ }^{53}$ Kasaai, M. R.; Arul, J.; Charlet, G. Fragmentation of chitosan by ultrasonic irradiation. Ultrasonics Sonochemistry 2008, 15, 1001. [CrossRef] [PubMed]

${ }^{54}$ Izidoro, D. R.; Sierakowski, M.-R.; Haminiuk, C. W. I.; de Souza, C. F.; Scheer, A. $P$. Physical and chemical properties of ultrasonically, spray-dried green banana (Musa cavendish) starch. Journal of Food Engineering 2011, 104, 639. [CrossRef]

${ }^{55}$ Li, J.; Cai, J.; Fan, L. Effect of sonolysis on kinetics and physicochemical properties of treated chitosan. Journal of Applied Polymer Science 2008, 109, 2417. [CrossRef]

${ }^{56}$ Bodmeier, R.; Maincent, P. Em Pharmaceutical Dosage Forms: Disperse Systems, Lieberman, H.; Rieger, M.; Banker, G., eds.; 2a. ed., vol. 3, CRC Press, 1998. [Link]

${ }^{57}$ Katiyar, D.; Hemantaranjan, A.; Singh, B.; Bhanu, A. N. Future Perspective in Crop Protection: Chitosan and its Oligosaccharides. Advances in Plants \& Agriculture Research 2014, 1, 6. [CrossRef]

${ }^{58}$ Kean, T.; Thanou, M. Biodegradation, biodistribution and toxicity of chitosan. Advanced Drug Delivery Reviews 2010, 62, 3. [CrossRef] [PubMed]

${ }^{59}$ Kong, M.; Chen, X. G.; Xing, K.; Park, H. J. Antimicrobial properties of chitosan and mode of action: A state of the art review. International Journal of Food Microbiology 2010, 144, 51. [CrossRef] [PubMed]

${ }^{60}$ Hernández-Lauzardo, A. N.; Bautista-Baños, S.; Velázquez-del Valle, M. G.; MéndezMontealvo, M. G.; Sánchez-Rivera, M. M.; Bello-Pérez, L. A. Antifungal effects of chitosan with different molecular weights on in vitro development of Rhizopus stolonifer (Ehrenb.:Fr.) Vuill. Carbohydrate Polymers 2008, 73, 541. [CrossRef] [PubMed]

${ }^{61}$ Chung, Y.-C.; Su, Y.-P.; Chen, C.-C.; Jia, G.; Wang, H.-I.; Wu, J. G.; Lin, J.-G. Relationship between antibacterial activity of chitosan and surface characteristics of cell wall. Acta Pharmacologica Sinica 2004, 25, 932. [PubMed]

Rev. Virtual Quim. |Vol 9| |No. 1| |387-409| 
${ }^{62}$ Zhong, Z.; Xing, R.; Liu, S.; Wang, L.; Cai, S.; $\mathrm{Li}, \mathrm{P}$. Synthesis of acyl thiourea derivatives of chitosan and their antimicrobial activities in vitro. Carbohydrate Research 2008, 343, 566. [CrossRef] [PubMed]

63 Wang, X.; Du, Y.; Liu, H. Preparation, characterization and antimicrobial activity of chitosan-Zn complex. Carbohydrate Polymers 2004, 56, 21. [CrossRef]

64 Jung, B.-O.; Kim, C.-H.; Choi, K.-S.; Lee, Y. M.; Kim, J.-J. Preparation of amphiphilic chitosan and their antimicrobial activities. Journal of Applied Polymer Science 1999, 72, 1713. [CrossRef]

${ }^{65}$ Liu, H.; Du, Y.; Wang, X.; Sun, L. Chitosan kills bacteria through cell membrane damage. International Journal of Food Microbiology 2004, 95, 147. [CrossRef] [PubMed]

${ }^{66}$ Leuba, J. L.; Stossel, P.; Chitosan and Other Polyamines: Antifungal Activity and Interaction with Biological Membranes, in Chitin in Nature and Technology, Muzzarelli, R.; Jeuniaux, C.; Gooday, G., eds.; Springer US, 1986, cap. 10. [Link]

${ }^{67}$ El Ghaouth, A.; Arul, J.; Asselin, A.; Benhamou, N. Antifungal activity of chitosan on post-harvest pathogens: induction of morphological and cytological alterations in Rhizopus stolonifer. Mycological Research 1992, 96, 769. [CrossRef]

${ }^{68}$ Sudarshan, N. R.; Hoover, D. G.; Knorr, D. Antibacterial action of chitosan. Food Biotechnology 1992, 6, 257. [CrossRef]

${ }^{69}$ Kong, M.; Chen, X.-G.; Xue, Y.-P.; Liu, C.-S.; Yu, L.-J.; Ji, Q.-X.; Cha, D.; Park, H. Preparation and antibacterial activity of chitosan microshperes in a solid dispersing system. Frontiers of Materials Science in China 2008, 2, 214. [CrossRef]

70 Papineau, A. M.; Hoover, D. G.; Knorr, D.; Farkas, D. F. Antimicrobial effect of water-soluble chitosans with high hydrostatic pressure. Food Biotechnology 1991, 5, 45. [CrossRef]

${ }^{71}$ Aiedeh, K.; Taha, M. O. Synthesis of ironcrosslinked chitosan succinate and ironcrosslinked hydroxamated chitosan succinate and their in vitro evaluation as potential matrix materials for oral theophylline sustained-release beads. European Journal of Pharmaceutical Sciences 2001, 13, 159. [CrossRef] [PubMed]

72 Uchida, Y.; Izume, M.; Ohtakara, A. Preparation of chitosan oligomers with purified chitosanase and its application, Chitin and Chitosan: Sources, Chemistry, Biochemistry, Physical Properties and Applications, ed. Elsevier. 1989, London, UK,. 9. [Link]

${ }^{73}$ Blagodatskikh, I. V.; Kulikov, S. N.; Vyshivannaya, O. V.; Bezrodnykh, E. A.; Yamskov, I. A.; Tikhonov, V. E. Influence of glucosamine on oligochitosan solubility and antibacterial activity. Carbohydrate Research 2013, 381, 28. [CrossRef] [PubMed]

74 Tokura, S.; Ueno, K.; Miyazaki, S.; Nishi, N. Molecular weight dependent antimicrobial activity by Chitosan. Macromolecular Symposia 1997, 120, 1. [CrossRef]

75 Tikhonov, V. E.; Stepnova, E. A.; Babak, V. G.; Yamskov, I. A.; Palma-Guerrero, J.; Jansson, H.-B.; Lopez-Llorca, L. V.; Salinas, J.; Gerasimenko, D. V.; Avdienko, I. D.; Varlamov, V. P. Bactericidal and antifungal activities of a low molecular weight chitosan and its $\mathrm{N}$-/2(3)-(dodec-2-enyl)succinoyl/derivatives. Carbohydrate Polymers 2006, 64, 66. [CrossRef]

${ }^{76}$ Lu, Y.; Sun, Q.; She, X.; Xia, Y.; Liu, Y.; Li, J.; Yang, D. Fabrication and characterisation of Ît-chitin nanofibers and highly transparent chitin films by pulsed ultrasonication. Carbohydrate Polymers 2013, 98, 1497. [CrossRef] [PubMed]

77 Takahashia, T.; Imaia, M.; Suzukia, I.; Sawai, J. Growth inhibitory effect on bacteria of chitosan membranes regulated by the deacetylation degree. Biochemical Engineering Journal 2008, 40, 6. [CrossRef]

${ }^{78}$ Gavhane, Y.; Gurav, A.; Yadav, A. Chitosan and its applications: a review of literature. International Journal of Biomedical and Pharmaceutical Sciences 2013, 4, 312. [Link]

${ }^{79}$ El-Sawy, N. M.; Abd El-Rehim, H. A.; Elbarbary, A. M.; Hegazy, E.-S. A. Radiation- 
induced degradation of chitosan for possible use as a growth promoter in agricultural purposes. Carbohydrate Polymers 2010, 79, 555. [CrossRef]

${ }^{80}$ Linden, J.; Stoner, R.; Knutson, K.; GardnerHughes, C. Organic Disease Control Elicitors. Agro FOOD Industry Hi Tech, 2000, Oct: p. 1215. [Link]

${ }^{81}$ USDA and N.a. EPA, Rule on Chitosan. 2007, Federal Register: Rules and Regulation. [Link]

${ }^{82}$ Bittelli, M.; Flury, M.; Campbell, G. S.; Nichols, E. J. Reduction of transpiration through foliar application of chitosan. Agricultural and Forest Meteorology 2001, 107, 167. [CrossRef]

${ }^{83}$ Hirano, S.; Yamamoto, T.; Hayashi, M.; Nishida, T.; Inui, H. Chitinase Activity in Seeds Coated with Chitosan Derivatives. Agricultural and Biological Chemistry 1990, 54, 2719. [CrossRef]

${ }^{84}$ Vasyukova, N.; Zinov'Eva, S.; Il'inskaya, L.; Perekhod, E.; Chalenko, G.; Gerasimova, N.; I'ina, A.; Varlamov, V.; Ozeretskovskaya, $\mathrm{O}$. Modulation of plant resistance to diseases by water-soluble chitosan. Applied Biochemistry and Microbiology 2001, 37, 103. [CrossRef]

${ }^{85}$ Chibu, H., Effects of chitosan applications on the growth of several crops. [Link]

${ }^{86}$ Brody, A. L. Nano and food packaging technologies converge. Food technology 2006. [Link]

${ }^{87}$ Luo, P. G.; Stutzenberger, F. J. Nanotechnology in the detection and control of microorganisms. Advances in applied microbiology 2008, 63, 145. [CrossRef]

${ }^{88}$ Aider, M. Chitosan application for active bio-based films production and potential in the food industry: Review. LWT - Food Science and Technology 2010, 43, 837. [CrossRef]

${ }^{89}$ Ziani, K.; Fernández-Pan, I.; Royo, M.; Maté, J. I. Antifungal activity of films and solutions based on chitosan against typical seed fungi. Food Hydrocolloids 2009, 23, 2309. [CrossRef]
${ }^{90}$ Shao, X.; Tu, K.; Tu, S.; Tu, J. A Combination of heat treatment and chitosan coating delays ripening and reduces decay in "Gala" apple fruit. Journal of Food Quality 2012, 35, 83. [CrossRef]

${ }^{91}$ Cuero, R. G.; Osuji, G.; Washington, A. Ncarboxymethylchitosan inhibition of aflatoxin production: Role of zinc. Biotechnology Letters 1991, 13, 441. [CrossRef]

${ }^{92}$ Moreira, M. R.; Roura, S. I.; Ponce, A. Effectiveness of chitosan edible coatings to improve microbiological and sensory quality of fresh cut broccoli. LWT - Food Science and Technology 2011, 44, 2335. [CrossRef]

${ }^{93}$ Moreira, M. R.; Pereda, M.; Marcovich, N. E.; Roura, S. I. Antimicrobial Effectiveness of Bioactive Packaging Materials from Edible Chitosan and Casein Polymers: Assessment on Carrot, Cheese, and Salami. Journal of Food Science 2011, 76, M54. [CrossRef] [PubMed]

${ }^{94}$ Schirmer, B. C.; Heiberg, R.; Eie, T.; Møretrø, T.; Maugesten, T.; Carlehøg, M.; Langsrud, S. A novel packaging method with a dissolving $\mathrm{CO} 2$ headspace combined with organic acids prolongs the shelf life of fresh salmon. International Journal of Food Microbiology 2009, 133, 154. [CrossRef] [PubMed]

${ }^{95}$ Tezotto-Uliana, J. V.; Fargoni, G. P.; Geerdink, G. M.; Kluge, R. A. Chitosan applications pre- or postharvest prolong raspberry shelf-life quality. Postharvest Biology and Technology 2014, 91, 72. [CrossRef]

${ }^{96}$ Shiekh, R. A.; Malik, M. A.; Al-Thabaiti, S. A.; Shiekh, M. A. Chitosan as a novel edible coating for fresh fruits. Food Science and Technology Research 2013, 19, 139. [CrossRef]

${ }^{97}$ Galgano, F.; Condelli, N.; Favati, F.; Di Bianco, V.; Perretti, G.; Caruso, $M$. Biodegradable packaging and edible coating for fresh-cut fruits and vegetables. Italian Journal of Food Science 2015, 27, 1 A. [CrossRef] 
${ }^{98}$ Debeaufort, F.; Quezada-Gallo, J.-A.; Voilley, A. Edible Films and Coatings: Tomorrow's Packagings: A Review. Critical Reviews in Food Science and Nutrition 1998, 38, 299. [CrossRef] [PubMed]

${ }^{99} \mathrm{Vu}$, K. D.; Hollingsworth, R. G.; Leroux, E.; Salmieri, S.; Lacroix, M. Development of edible bioactive coating based on modified chitosan for increasing the shelf life of strawberries. Food Research International 2011, 44, 198. [CrossRef]

${ }^{100}$ Velickova, E.; Winkelhausen, E.; Kuzmanova, S.; Alves, V. D.; Moldão-Martins, M. Impact of chitosan-beeswax edible coatings on the quality of fresh strawberries (Fragaria ananassa cv Camarosa) under commercial storage conditions. LWT - Food Science and Technology 2013, 52, 80. [CrossRef]

${ }^{101}$ Elsabee, M. Z.; Abdou, E. S. Chitosan based edible films and coatings: A review. Materials Science and Engineering: C 2013, 33, 1819. [CrossRef] [PubMed]

${ }^{102}$ Colinet, I.; Dulong, V.; Mocanu, G.; Picton, L.; Le Cerf, D. Effect of chitosan coating on the swelling and controlled release of a poorly water-soluble drug from an amphiphilic and $\mathrm{pH}$-sensitive hydrogel. International Journal of Biological Macromolecules 2010, 47, 120. [CrossRef] [PubMed]

${ }^{103}$ Han, C.; Zhao, Y.; Leonard, S. W.; Traber, M. G. Edible coatings to improve storability and enhance nutritional value of fresh and frozen strawberries (Fragaria $\times$ ananassa) and raspberries (Rubus ideaus). Postharvest Biology and Technology 2004, 33, 67. [CrossRef]

${ }^{104}$ Hong, K.; Xie, J.; Zhang, L.; Sun, D.; Gong, D. Effects of chitosan coating on postharvest life and quality of guava (Psidium guajava L.) fruit during cold storage. Scientia Horticulturae 2012, 144, 172. [CrossRef]

${ }^{105}$ Rungsardthong, V.; Wongvuttanakul, N.; Kongpien, N.; Chotiwaranon, P. Application of fungal chitosan for clarification of apple juice. Process Biochemistry 2006, 41, 589. [CrossRef]
${ }^{106}$ Yen, M.-T.; Yang, J.-H.; Mau, J.-L. Antioxidant properties of chitosan from crab shells. Carbohydrate Polymers 2008, 74, 840. [CrossRef]

${ }^{107}$ Rajalakshmi, A.; Krithiga, N.; Jayachitra, A. Antioxidant activity of the chitosan extracted from shrimp exoskeleton. Middle-east Journal of Scientific Research 2013, 16, 1446. [CrossRef]

${ }^{108}$ Ratkovich, N.; Horn, W.; Helmus, F.; Rosenberger, S.; Naessens, W.; Nopens, I.; Bentzen, T. R. Activated sludge rheology: a critical review on data collection and modelling. Water Research 2013, 47, 463. [CrossRef] [PubMed]

${ }^{109}$ Radhakrishnan, Y.; Gopal, G.; Lakshmanan, C. C.; Nandakumar, K. S. Chitosan Nanoparticles for Generating Novel Systems for Better Applications: A Review. Journal of Molecular and Genetic Medicine 2015, 2015. [CrossRef]

${ }^{110}$ Joye, I. J.; McClements, D. J. Biopolymerbased nanoparticles and microparticles: fabrication, characterization, and application. Current Opinion in Colloid \& Interface Science 2014, 19, 417. [CrossRef]

${ }^{111}$ Avella, M.; De Vlieger, J. J.; Errico, M. E.; Fischer, S.; Vacca, P.; Volpe, M. G. Biodegradable starch/clay nanocomposite films for food packaging applications. Food Chemistry 2005, 93, 467. [CrossRef]

${ }^{112}$ Chau, C.-F.; Wu, S.-H.; Yen, G.-C. The development of regulations for food nanotechnology. Trends in Food Science \& Technology 2007, 18, 269. [CrossRef]

${ }^{113}$ Zhao, L.-M.; Shi, L.-E.; Zhang, Z.-L.; Chen, J.-M.; Shi, D.-D.; Yang, J.; Tang, Z.-X. Preparation and application of chitosan nanoparticles and nanofibers. Brazilian Journal of Chemical Engineering 2011, 28, 353. [CrossRef]

${ }^{114}$ Lertsutthiwong, P.; Rojsitthisak, P. Chitosan-alginate nanocapsules for encapsulation of turmeric oil. Die PharmazieAn International Journal of Pharmaceutical Sciences 2011, 66, 911. [CrossRef] 
${ }^{115}$ Taylor, H. F.; Vitamin preparation and method of making same, US2348503 A, 1939. [Link]

${ }^{116}$ de Vos, P.; Faas, M. M.; Spasojevic, M.; Sikkema, J. Encapsulation for preservation of functionality and targeted delivery of bioactive food components. International Dairy Journal 2010, 20, 292. [CrossRef]

${ }^{117}$ Sekhon, B. S. Food nanotechnology-an overview. Nanotechnology, Science and Applications 2010, 3, 1. [CrossRef] [PubMed]

${ }^{118}$ Alishahi, A.; Aïder, M. Applications of chitosan in the seafood industry and aquaculture: a review. Food and Bioprocess Technology 2012, 5, 817. [CrossRef]

${ }^{119}$ Yang, F.; Xia, S.; Tan, C.; Zhang, X. Preparation and evaluation of chitosancalcium-gellan gum beads for controlled release of protein. European Food Research and Technology 2013, 237, 467. [CrossRef]

${ }^{120}$ Silva, C. M.; Ribeiro, A. J.; Figueiredo, M.; Ferreira, D.; Veiga, F. Microencapsulation of hemoglobin in chitosan-coated alginate microspheres prepared by emulsification/internal gelation. The AAPS Journal 2005, 7, E903. [CrossRef] [PubMed]

${ }^{121}$ Alishahi, A.; Mirvaghefi, A.; Tehrani, M.; Farahmand, H.; Koshio, S.; Dorkoosh, F.; Elsabee, M. Z. Chitosan nanoparticle to carry vitamin $\mathrm{C}$ through the gastrointestinal tract and induce the non-specific immunity system of rainbow trout (Oncorhynchus mykiss). Carbohydrate Polymers 2011, 86, 142. [CrossRef]

${ }^{122}$ Alishahi, A.; Mirvaghefi, A.; Tehrani, M.; Farahmand, H.; Shojaosadati, S.; Dorkoosh, F.; Elsabee, M. Z. Shelf life and delivery enhancement of vitamin C using chitosan nanoparticles. Food Chemistry 2011, 126, 935. [CrossRef]

${ }^{123}$ Rajeshkumar, S.; Venkatesan, C.; Sarathi, M; Sarathbabu, V.; Thomas, J.; Basha, K. A.; Hameed, A. S. Oral delivery of DNA construct using chitosan nanoparticles to protect the shrimp from white spot syndrome virus (WSSV). Fish \& Shellfish Immunology 2009, 26, 429. [CrossRef] [PubMed]
${ }^{124}$ Peniche, C.; Howland, I.; Carrillo, O.; Zaldıvar, C.; Argüelles-Monal, W. Formation and stability of shark liver oil loaded chitosan/calcium alginate capsules. Food Hydrocolloids 2004, 18, 865. [CrossRef]

${ }^{125}$ Klinkesorn, U.; McClements, D. J. Influence of chitosan on stability and lipase digestibility of lecithin-stabilized tuna oil-in-water emulsions. Food Chemistry 2009, 114, 1308. [CrossRef]

${ }^{126}$ Souza, H. K. S.; Campiña, J. M.; Sousa, A. M. M.; Silva, F.; Gonçalves, M. P. Ultrasoundassisted preparation of size-controlled chitosan nanoparticles: Characterization and fabrication of transparent biofilms. Food Hydrocolloids 2013, 31, 227. [CrossRef]

${ }^{127}$ Martínez-Camacho, A. P.; Cortez-Rocha, M. O.; Ezquerra-Brauer, J. M.; GracianoVerdugo, A. Z.; Rodriguez-Félix, F.; CastilloOrtega, M. M.; Yépiz-Gómez, M. S.; Plascencia-Jatomea, M. Chitosan composite films: Thermal, structural, mechanical and antifungal properties. Carbohydrate Polymers 2010, 82, 305. [CrossRef]

${ }^{128}$ Yang, T.-C.; Chou, C.-C.; Li, C.-F. Antibacterial activity of $\mathrm{N}$-alkylated disaccharide chitosan derivatives. International Journal of Food Microbiology 2005, 97, 237. [CrossRef] [PubMed]

${ }^{129}$ Abugoch, L. E.; Tapia, C.; Villamán, M. C.; Yazdani-Pedram, M.; Díaz-Dosque, $M$. Characterization of quinoa protein-chitosan blend edible films. Food Hydrocolloids 2011, 25, 879. [CrossRef]

${ }^{130}$ Khunawattanakul, W., Puttipipatkhachorn, S.; Rades, T.; Pongjanyakul, T. Novel chitosan-magnesium aluminum silicate nanocomposite film coatings for modified-release tablets. International Journal of Pharmaceutics 2011, 407, 132. [CrossRef] [PubMed]

${ }^{131}$ Ai, H.; Wang, F.; Xia, Y.; Chen, X.; Lei, C. Antioxidant, antifungal and antiviral activities of chitosan from the larvae of housefly, Musca domestica L. Food Chemistry 2012, 132, 493. [CrossRef] [PubMed]

Rev. Virtual Quim. |Vol 9| |No. 1| |387-409| 
${ }^{132}$ Devlieghere, F.; Vermeulen, A.; Debevere, J. Chitosan: antimicrobial activity, interactions with food components and applicability as a coating on fruit and vegetables. Food Microbiology 2004, 21, 703. [CrossRef]

${ }^{133}$ Georgantelis, D.; Blekas, G.; Katikou, P.; Ambrosiadis, I.; Fletouris, D. J. Effect of rosemary extract, chitosan and $\alpha$-tocopherol on lipid oxidation and colour stability during frozen storage of beef burgers. Meat Science 2007, 75, 256. [CrossRef] [PubMed]

${ }^{134}$ Albertengo, L.; Farenzena, S.; Debbaudt, A.; Zuñiga, A.; Schulz, P.; Rodriguez, M. S. Physico-chemical studies and emulsifying properties of $\mathrm{N}$-propyl-N-methylene phosphonic chitosan. Carbohydrate Polymers 2013, 92, 1641. [CrossRef] [PubMed]
${ }^{135}$ Carreau, P. J. Rheological equations from molecular network theories. Transactions of The Society of Rheology (1957-1977) 1972, 16, 99. [CrossRef]

${ }^{136}$ Maezaki, Y.; Tsuji, K.; Nakagawa, Y.; Kawai, Y.; Akimoto, M.; Tsugita, T.; Takekawa, W.; Terada, A.; Hara, H.; Mitsuoka, T. Hypocholesterolemic Effect of Chitosan in Adult Males. Bioscience, Biotechnology, and Biochemistry 1993, 57, 1439. [CrossRef]

${ }^{137}$ Borges, J.; Campiña, J. M.; Silva, A. F. Chitosan biopolymer- $F \quad\left(a b^{\prime}\right) \quad 2$ immunoconjugate films for enhanced antigen recognition. Journal of Materials Chemistry $B$ 2013, 1, 500. [CrossRef]

${ }^{138}$ Borman, S. Push for new materials, chemicals from biomass sparks active $R$ and D. Chemical and Engineering News (USA) 1990, 68, 19. [CrossRef] 